\title{
Nation Building in Bosnia and Herzegovina : Cooperation, Coordination and Collaboration
}

\section{Eric C. Martin}

\begin{abstract}
Cross-sectoral interorganizational relationships in post-conflict situations occur regularly. Whether formal task forces, advisory groups or other ad hoc arrangements, these relations take place in chaotic and dangerous situations with urgent and turbulent political, economic and social environments. Furthermore, they typically involve a large number of players from many different nations, operating across sectors, and between multiple layers of bureaucracy and diplomacy. The organizational complexity staggers many participants and observers, as do the tasks they are charged with completing.

Reform efforts in Bosnia and Herzegovina starting in 1995 may serve as the archetype model of conflict, transition and development for the 21st century. It wins this honor due not to its particular programmatic successes and failures, rather to the interorganizational complexity of the International Community. From the massive response to the crisis, to the modern nation-building policies it spawned, and the development assistance practices and institutional arrangements it created, the Bosnian development experience has much to offer by way of lessons learned.

This manuscript frames the unique Bosnian development situation, and provides lessons learned from the experience of nation building given local realities. Pettigrew (1992) called this "contextualizing." While network and/or organizational structure, strategy and process explain many interorganizational relationship issues, the development variables identified in this manuscript prove equally important, yet elusive and difficult to measure despite their very real and overt presence.
\end{abstract}

Key words: International Development, Interorganizational Relationships, Bosnia and Herzegovina

JEL: $011,019,052$

DOI: $10.2478 / v 10033-007-0001-5$

\section{Introduction}

Much has been written about the need for development assistance organizations to better coordinate their activities, cooperate across sectors, plan for long-term stays in countries, and implement partnerships with locals to transfer knowledge over time. Much also has been made of the need for country-specific responses to crises. And finally, much has been made about the need for 'lessons learned' and 'best practices' pieces that can be used to compare nation building experiences. This article treads lightly between the three. Cross-sectoral interorganizational relationships in complex humanitarian emergencies (CHEs) or nation building efforts often take place in chaotic and dangerous situations with extreme urgency and a large num- bers of players; in turbulent political, economic and social environments; and with multiple layers of bureaucracy and diplomacy, from many different nations.

\footnotetext{
*Eric C. Martin, PhD.

Department of Business Administration Eastern Connecticut State University, 83 Windham Street, Willimantic, CT 06226 (860) 465-0245 voice (860) 465-4469 fax MartinE@EasternCT.edu
} 
Bosnian nation building or reform efforts starting in 1995 may serve as the last great nation-building effort of the 20th century, and given developments to date in Kosovo, East Timor, Afghanistan, and Iraq, perhaps the archetype model of conflict, transition and development for the $21^{\text {st }}$ century. It wins this honor due not to its particular successes and failures, rather to the interorganizational complexity of the International Community's response to the crisis, the modern nation-building policies it spawned and the development assistance practices and institutional arrangements it created.

In the pages that follow, I highlight opportunities and obstacles to cooperative, coordinated and collaborative development assistance efforts in Bosnia and Herzegovina (or $\mathrm{BiH})$. While network and organizational structure, strategy and process explain many interorganizational relationship issues, the variables identified below can prove dramatically important at times, and yet remain surprisingly elusive to both observers and participants despite their very real and overt presence. Relationships do not take place in a vacuum. The influence of exogenous variables proves dramatic. Pettigrew (1992) called this "contextualizing." Solutions require that organizations with the capacity and incentive be willing to work together.

This work is based on extensive field experience in Bosnia and Herzegovina researching interdisciplinary task forces, networks, forums and groups of almost every conceivable combination of players across a variety of topics that cut across sectors. I explored the protection of journalists, privatization of state-owned enterprises, refugee return, regulation of media, economic development, harmonization of entity tax laws and legal reform. Research took place at a variety of levels; from high level donor conferences, and diplomatic efforts of the Peace Implementation Committee, to the various Sectoral Task Forces, each with their own lead organizations, to the more grassroots implementation level coordination bodies, ad hoc committees and advisory groups among country offices.

For this manuscript, I focus on the roles and actions of the key international community players that had a hand in several of the different task forces mentioned above. The key bilateral assistance agencies include USAID, GTZ, DFID, and the EU. The World Bank, IMF, EBRD, and dozens of NGOs and other implementing partners also played critical roles. My goal is to identify obstacles and opportunities for success in $\mathrm{BiH}$ that might inform similar nation-building difficulties in other settings. I do so through a qualitative analysis of task force meetings and in-depth interviews with nearly 200 development professionals from 1999-2005 throughout the Balkans.

\section{Background to Bosnian Develop- ment ${ }^{1}$}

My research allowed me to become familiar not only with the work of these professionals, to know them personally as well, as the $\mathrm{BiH}$ expatriate community is rather tight-knit. Many development professionals, especially contractors, that I interviewed 'cut their teeth' in Central and Eastern Europe. They then moved over time to work in countries that seemed to follow the CEE model of transition and development (i.e. Poland, Czech Republic, Slovakia, Hungary, Lithuania, Estonia, Latvia, Romania, Bulgaria, and many Former Soviet States). These countries adopted broadly similar paths (perhaps because they were being implemented by the same international players) regarding traditional development coupled with the complex transition from central planning to free-market capitalism and democracy. Of course, locals, scholars and practitioners were keen to mention the importance of adapting larger models of change that were sensitive to local conditions in each country. Many worried about "cookie-cutter" models that were not specifically altered to fit local cultures, historical realities, circumstances, particular relationships with neighboring countries, etc.

According to my interviews, experiences and observations, many of these individuals found themselves in $\mathrm{BiH}$ by 1997 and $1998^{2}$. They were likely hired based on their extensive reform experiences in Central and Eastern Europe, but appeared shocked and troubled by the complexities of change and transition in Bosnia. The ethnic conflict in BiH added an additional obstacle to their work that many had not faced so overtly elsewhere. This complexity, not only as a task in and of itself, but as a mediating variable on other transition

\footnotetext{
1 Overviews of the development situation in Bosnia and Herzegovina, as it progressed from conflict to post-conflict, transition and development can be found elsewhere. I need not repeat the story here. For clarity, and as a caveat to my overal orientation, I generally conform to the opinions of International Crisis Group and European Stability Initiative reports
}

2 This was largely true of many contractors. It was less evident with career professionals in assistance agencies who seemed to have much broader experiences, having spent time throughout the world. 
and development tasks, coupled with the very complex Dayton Peace Accords, which serve as the nation's constitution, made even the simplest of reforms very difficult.

The Office of the High Representative (OHR), Bosnia and Herzegovina's interim authority added an additional complexity. Unlike much of Central and Eastern Europe, reform in $\mathrm{BiH}$ could not initially take place within existing government and political channels, so the peace settlement mandated an outside authority to take control of events. This policy change dramatically altered working relationships between the various assistance arms of governments, multilateral institutions and NGOs. Military needs and peacekeeping operations by NATO and others added yet an additional layer of complexity to any reform measure.

Reformers reported that $\mathrm{BiH}$ was indeed a unique development situation quite unlike those found throughout CEE, even though the tasks and ultimate goals were largely similar. In other words, the context in which these reforms took place proved influential. So reformers in Bosnia and Herzegovina largely forged ahead into uncharted waters.

However, since the crisis in $\mathrm{BiH}$, we have seen several similar situations where transition and development reform initiatives also required post-conflict measures. Kosovo, East Timor, Afghanistan and Iraq, among others, are all going through this threefold change. As such, a model has emerged where multiple players, from many countries, across the three sectors, must work together to solve problems that cannot be solved in a neat linear fashion and change rapidly over time. In the pages below, I explore and identify the complexity that development assistance players face in working together in such an environment.

\section{Cooperation, Coordination and Col- laboration in International Develop- ment: Literature}

To understand the nation-building process, in Bosnia and Herzegovina or anywhere else, careful attention must be paid to those organizations designated to assist or control that change. In particular, attention must be paid to the relationships (at times peculiar, competitive or downright antagonistic) they have with each other. While interorganizational relationships are crucial to implementing reform and change, they are often wrought with difficulties, obstacles and confusion. However, these are the institutions of col- laboration that help build nations and implement foreign policy. Success or failure of these groups has implications for reform success more generally. This study anchors itself to these interorganizational vehicles and explores development within the context of the IORs that implement development policy and translate high-level objectives into ground level action.

A solid body of work targets complex development cases and the interorganizational dynamics within. I paid particular attention to cases involving conflict, transition and development. Much has been written about $\mathrm{BiH}$, particularly by the think tanks International Crisis Group and the European Stability Initiative ${ }^{3}$. These represent valuable sources for understanding progress and change over time by researchers with extensive experience on the ground. Research in Bosnia and Herzegovina also targets nation building efforts more generally (Talentino, 2002) as well as studies of the electoral process (Belloni, 2004), privatization (Donais, 2002; Martin, 2004), and the relationships among NGOs in the country (Martin and Miller, 2003). Huddleston (1999) provides a unique analysis of the constraints he observed as a consultant in Bosnia.

Examples from other settings proved equally informative such as Hill's (2001) discussion of East Timor's development challenges; several articles targeting El Salvador (Boyce, 1995a,b; Castillo, 2001), Francis' (2000) coverage of Sierra Leone, Roberts and Bradley's (2005) research in Afghanistan, Borton's (1995) summary of the Rwandan crisis and Ofstad's (2002) analysis of Sri Lanka4. The research reported here holds these works as exemplars in their efforts to balance an understanding of macro development policy challenges with grounded, field-level perspectives based on those implementing projects. Perhaps more importantly, these works also address the process through which the more macro policy desires trickle down to actual project results and coordination efforts, as well as the reverse, how grounded efforts resulted in large scale change.

More macro models of post-conflict development help shape understanding of national needs in terms of reconstruction and nation-building generally. Hamre and Sullivan (2002: p. 92) identified the four "pillars" of post-conflict reconstruction. Security refers to the development of

3 See also, Knaus and Martin, 2003. Though ESI authors, this work came out in the Journal of Democracy.

4 See also Lammers (1988) for a unique but related case of the German occupation of Belgium, the Netherlands and Norway during the Second World War. 
fair, legitimate and effective security institutions, as well as overall public safety. Justice and reconciliation refers to the need for an impartial and accountable legal system in addition to the ability to address past abuses. Social and economic well-being addresses emergency relief, health and education, and sustainable economic development. Finally, governance and participation refers to the institutions of government, public administration, transparent and accountable political activity and the development of a vibrant and engaged civil society. The question of strategy in implementing such reforms weighs heavily in this analysis and requires local leadership, international community support to leverage local advances, unity of effort, sequencing and planning of reform actions, and perseverance within what might be a longer timetable than some desire (Hamre and Sullivan, 2002).

The SCOPE model of Sustainable Communities in Post-conflict Environments (Hasic and Bhandari, 2002; Hasic 2006) provides another comprehensive and holistic overview of the complexity of conflict, the interconnectedness of issues and the dynamics of change over time. This model also puts forth a variety of priority needs areas.

- Physical - Rehabilitation of neighborhoods, regional planning, and infrastructure;

- $\quad$ Economic - Property rights, economic base, private sector development;

- Social - Cultural heritage, security and reconciliation, inclusion, civil society

- Political - Institutions and law, consensus, gover nance

- Technological - Knowledge and capital, R\&D, infra structure, and technology

- Environmental - protection, conservation, health, pollution, risk

- Cultural - customs, tradition, ethnicity, education, c reativity, diversity

The line of research above frames the presentation of cross-sectoral and international task forces that address sector-specific action. I employ another set of research that more overtly targets interorganizational relationships and coordination mechanisms in development settings to potentially address such interdisciplinary needs in a strategic, cooperative, coordinated manner.
This set of work identifies important cross-sectoral, typically international, interorganizational processes as key variables in development. Scholars have explored networks that empowered women in Costa Rica (Vargas, 2002); preserved global biodiversity (Westley and Vrendenburg, 1997); implemented Madagascar's environmental action plan (Brinkerhoff, 1996); and supported refugees in the United Kingdom (Hardy and Phillips, 1998; Lawrence and Hardy, 1999). Pugh (2000) and Walker (1993) specifically target NGO-military relationships. Clark (1995) addressed civil society interventions and the important interplay between donors, NGOs and local stakeholders. These cases all had similar tensions between players, common rationales for cooperative action, and very real obstacles to achieving those ends. Written largely from an organizational or managerial perspective, these works are also complemented by studies of strategic thinking and management in development settings (Kiggundo, 1996; Goldsmith, 1996) and organizational learning in development institutions (Ellerman, 1999).

Another stream of work looks at the situation in a more reflective manner, illustrating inherent problems, and potential solutions. Lord Judd of Portea (1992) blasts the international community in his provocatively titled "Disaster Relief or Relief Disaster" for their failures, waste and inefficiencies, imploring stakeholders to work together more effectively. Others seek to categorize and codify trends and implications of current aid practices (Weiss, 2001; Maley, 2002; Griffin, 2000; Pritchett and Woolcock, 2004), all strongly suggest the need for more coordinated, strategic and effective networks for both policy development and subsequent interventions or implementations, despite overwhelming and very tangible obstacles to doing so.

A final line of research provides templates and models of effective coordination mechanisms. Roberts and Bradley (2005) set forth four key organizing forms that include the traditional 1) ad-hoc approach as well as 2) command and control or hierarchical efforts, 3) market based efforts where efficiencies might be found to partners' mutual benefit and 4) community approaches where the beneficiary seems the ultimate goal in more holistic efforts to simultaneously target multiple needs. Ricigliano (2003) proposes networks of effective action (NEAs) to identify how different players with varying needs and skills can work together (reminiscent of Roberts and Bradley's community approach). A variety of studies target the particular difficulties of cross-sector coordination efforts and relationships between donors, host country governments, bilateral assistance agencies, NGO 
implementers, corporations and multilateral organizations (Brinkerhoff, D. 1999; Brinkerhoff, J. 2002; Brinkerhoff and Brinkerhoff, 2002a,b, 2004; Evans, 1996; Martin, Faerman and McCaffrey, 2006; Rondinelli and Black, 2000; Rondinelli and London, 2003).

In keeping with this niche of organizational, interorganizational and development literature, the study below attempts to provide an understanding of the context of development assistance in $\mathrm{BiH}$, with an overview of the key players and their backgrounds, including institutional, organizational and managerial constraints. I frame this within the templates and models provided above, to specifically explore ground-level obstacles to the process of more coordinated, cooperative interorganizational relationships that address multiple, and at times, competing needs, in development settings, as observed and reported by professionals involved in such efforts.

\section{Cooperative, Coordinated and Col- laborative Institutions in Bosnia and Herzegovina}

In this section, I introduce several different coordinating bodies and task forces operating in $\mathrm{BiH}$ to provide some understanding of the complex relationships in such settings, and to establish the cases from which I draw insight. They involve different players that target different activities. And they take place at different levels, with different types of participants, aims, goals and strategies. However, I find them remarkably similar regarding 1) The context within which they worked; 2) The organizations involved; and 3) The managerial issues they faced.

The Refugee Return \& Reconstruction Task Force (RRTF) was established by the Peace Implementation Committee to coordinate donors and implementers working on a wide variety of refugee issues. The UNHCR (High Commission on Refugees) and the OHR co-chaired the RRTF, as mandated by the Peace Implementation Committee (PIC). Literally hundreds of NGOs and bilateral agencies participated in RRTF activities.

The International Council of Voluntary Agencies (ICVA) played an important coordinating role in the NGO community by organizing meetings and conferences, working to partner local NGOs with internationals and generally serving as an advocate for NGO positions. This group created and then evolved into the NGO Council, yet another coordinating body, that gradually transformed itself from an internationally-led and dominated organization to a largely local one.

International activities in media were initially coordinated through Media Roundtable meetings, chaired by the OHR, which evolved into the Media Issues Group (MIG). The OHR was involved in media through its concern for human rights and its general coordination role, which makes it an important player in every sector. The OSCE targeted media based upon its concern with elections and democratization. The OHR-created Independent Media Commission (IMC) and Open Broadcast Network (OBN) were also important players, serving as BiH's telecommunication regulatory agency and public television station respectively. NATO was also involved in media, primarily concerned with frequency distribution, and instances where force was necessary to shut down illegal broadcasters.

The International Advisory Group on Privatization (IAGP) served as an important task force, modeled after the IAG on Payment Bureau Reform, and serving as the model for the IAG on Tax Harmonization. IAGP member organizations implemented privatization-related reforms on behalf of the PIC; though each had seemingly distinct mandates, objectives, skills and resources. Many participants and observers suggest this task force was one of the best examples of coordinated cooperative international activity.

Finally, the Bulldozer Committee was launched in the end of 2002. It stemmed from a speech made by the then High Representative, Paddy Ashdown, who stressed that business people needed to help the country "bulldoze" pointless regulations and red tape that made it harder for companies to create jobs and prosperity (NY Times, 10/28/03). The OHR pushed this initiative, backing it with press and fanfare. They sponsored meetings across the country to bring together business leaders, explain the program to them, and ask for their input about regulations that prevent growth and good business. International players helped insure that any proposed changes conformed to other reforms and didn't cause any additional regulatory concerns. They also helped push reforms through local government channels.

As if these groups weren't complex enough, efforts were also made through informal arrangements at the implementation level, as well as much more formal diplomatic channels at higher levels such as donor conferences, to harmonize 
activity not just within each of these individual task forces, but between them to insure the overarching nation building efforts would be achieved and sustained. For example, to return refugees to their homes required rebuilding, but also required the need for employment, which relied upon economic development, privatization and legal reform. Nation building is indeed a serious and complex undertaking.

\section{Methods}

This paper stems from research conducted over the course of five field trips, based in Sarajevo, the capital of Bosnia and Herzegovina, from 1999-2005 for a total of eight months in the country. In all, 182 senior executives, diplomats, mid- and upper-level managers, staff and consultants from over 30 national, international and multinational organizations were interviewed. Interview lengths ranged from 20 minutes to over 4 hours, with some key individuals being interviewed several times. Several individuals were interviewed annually, providing an excellent perspective regarding change over time. In other situations, personnel changed, thus permitting interviews of different individuals serving the same role in the same organization at different times. Over fifty hours of interviews were tape recorded, transcribed and coded. The rest were reproduced using detailed notes as soon after the interview as possible. In addition, many informal interviews also took place over dinners, lunches and other social events. These informal conversations served to bolster subsequent lines of questioning. I also attended many conferences and task force meetings across the sectors.

Many of the same players (organizational and/or individual) tended to reappear over the course of the field research effort, suggesting that the group of individuals interviewed represented the core organizations involved in development efforts. In addition, interviewees were asked to comment on other major players in their field. Those leads were followed up wherever possible, confirming balance and saturation. Interviews with more peripheral or niche players proved equally rewarding, and balanced the sample in many respects.

Table 1 provides a synopsis of the organizations represented in this research (i.e. representatives interviewed), according to the various task forces with which they were involved and/or about which they commented during interviews. Several organizations appear in multiple task forces. The individuals representing those organizations in different sector-specific activities, however, were different in most, if not all cases.

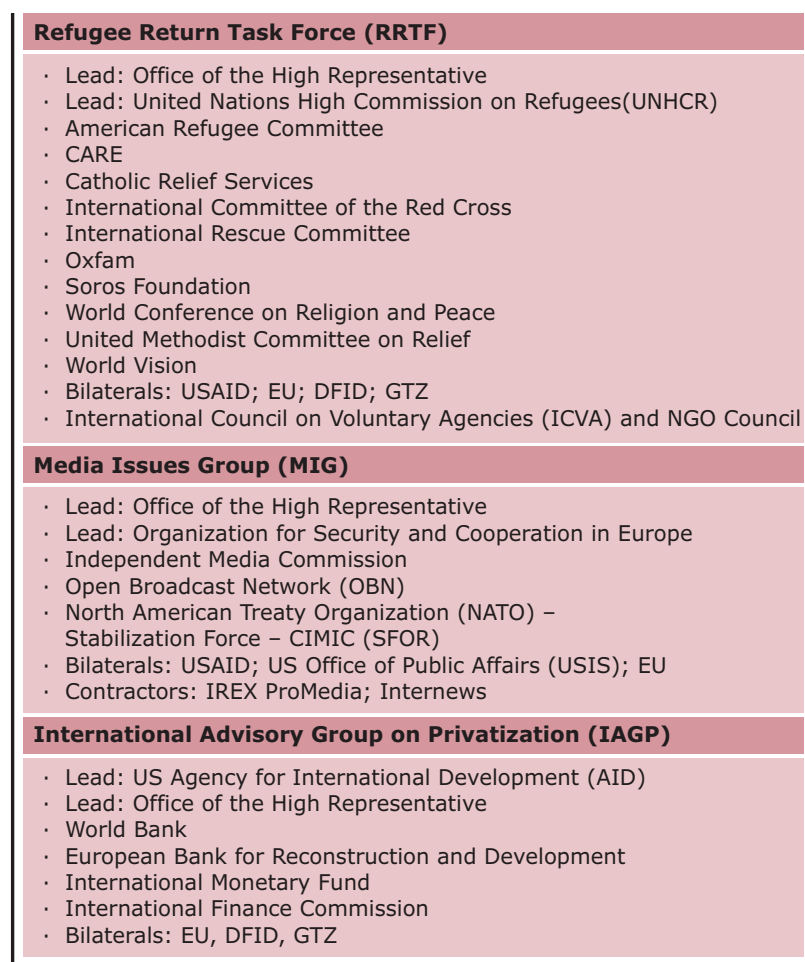

Table 1.

Representatives interviewed, by task force

\section{Opportunities for Cooperative, Coor- dinated and Collaborative Action}

Nearly all professionals in all the groups expressed some desire - the relative weight of that desire varied, but a desire nonetheless - to improve their interactions with other organizations. The rationale was almost unanimous. They worked together to improve the overall effectiveness of the work of the entire international community. Few overtly spoke of the desire to use these groups to enhance only their own organization's work. Beneficiaries were their overarching concern. The professionals I interviewed were able to spot gaps in service, inadequacies in programs and oversights in planning. They were aware that no one could consider everything and they were all constrained whether due to poor staffing, budget issues, politics or interpersonal problems. Some saw improvements in relationships between organizations as a catchall - a band-aid and a panacea. Others were more pragmatic, if not skeptical.

The following motivations for coordinated activity seemed to emerge from those with whom I spoke. Table 2 provides 
a summary of the findings.

Providing a Forum. Many stressed the need to simply provide a forum where those working in the sector could meet and discuss issues. Overwhelmingly, respondents suggested that the major motivator for improving cooperative action through such forums was diminishing funds. Essentially, they were forced to do more with fewer resources and thus sought external support.

We are cooperating a lot more the smaller we get, I've been noticing that in the last 5 months, as we draw down everybody else draws down, and there is so much more cooperation now. When you are expanding you are much more aggressive. Now that people are going down a little bit, there is less of that aggressiveness.

Most participant responses regarding information exchange, sharing of best practices, and learning about the activities of other organizations, problems and successes were coded into this category.

Identifying Niches and Overlap. Avoiding overlap and duplication was perhaps the most salient motivator, since most NGOs, for example, were grant-based and could not afford to waste donor money on projects that competed with others. Donors mentioned their desire not to see their money used to cancel itself out, but rather used to find synergies. One NGO director mentioned, "Obviously a donor doesn't want us to establish an information center right next to where another donor does."

One of the reasons why it is good to get people together is to avoid duplication. Donors would have an interest in not having money duplicated, either in the same areas of work or in the same physical regions. Some donors now insist that people get together and share, but they could do more in actually making that happen.

With this effort to avoid duplication and to identify areas that would easily be funded by donors, many NGOs looked to find niches in which they could specialize. Once known for a particular activity or area, NGOs could better identify potential partners. However, as more NGOs found niches, coordination became even more important to insure that gaps were not missed. "Where agencies are growing and they're willing to address different sector problems, they kind of divide off, then coordination becomes crucial." Into this category I coded concerns regarding efficiency as the primary motivator for coordinated activity; the need to achieve more with less, to better assist their beneficiaries.
Strength in Numbers. Most participants felt strongly that cooperative action could strengthen their collective positions through an advocacy role. This was an important motivator, not only in terms of more effectively addressing tasks, but also in improving the collective perceptions of NGOs within the international community.

ICVA does that a lot, they sort of act as a voice for all of us as a group so that none of us have to go out on a limb alone. I'm not going to hang out here and get shot by myself, but ICVA does it in the name of the NGO community.

While I found agreement on a relatively small number of common motivators for collective action, I found more disagreement, and a great many more concerns that seemed to present obstacles to coordinated activity. I coded these under three large themes concerning contextual concerns, organizational issues, and managerial problems.

\section{7a. Obstacles to Cooperative Action}

Obstruction. One local commented, "To have peace you have to have a winner, I think that is a general philosophical point. Here there is no clear winner so you cannot really have peace." This, coupled with inconsistencies in the Dayton accords themselves, ("on one side it upholds a multiethnic Bosnia but at same time, it cements in ethnic conflict and divisions.") complicated the task of refugee return and reconstruction. The Bosnians often did not share the IC's goals and objectives.

As a result, locals obstructed many specific reform efforts. In addition, locals felt somewhat powerless over their own government, which was propped up at the highest levels by the international community through SFOR and OHR. Where the Bosnian government did act independently, the three-way ethnic divisions hampered agreement and forced the internationals into the role of constant arbitrator. One bilateral official commented that, "they can't even sit in the same room together." In addition, corrupt and nationalist politicians, some indicted on war crimes, often held great power, having been legitimized by the 1996 elections. Locals, as such, often bargained with development organizations regarding implementation of reform efforts.

There is this whole dance. It's a vicious circle. Local officials are not empowered so donors don't use them and donors don't use them because they continue to show themselves as incompetent. 
Dramatic funding drop. The massive reduction in funding served to alter early activity and also provide an impetus to coordinate actions more thoroughly. Many suggested that the overall funding was in fact too large in the beginning, especially compared to assistance efforts in other parts of the world. The NGOs especially felt funding was not only too large, but also too focused on short-term results. Many organizations saw major cuts by 1999 and 2000 that had significant effects on their operations.

Geneva will mandate our funding down further and further so that eventually everyone will leave. We can certainly see the immediate effect of this. With the $50 \%$ cut, we can only do half what we did.

We're phasing out because of donor burnout, as much as anything else. USAID is not going to fund us for a fifth year. There is going to be no more emergency feeding after this month.

The drop in funding was partially due to the end of the Priority Reconstruction Project, the major source of funds in refugee return and reconstruction. However, the crisis in Kosovo also diverted donor attention. One worker suggested, "the way Bosnia now factors on the world stage, it is of much lower significance, there's no war anymore."

We saw Kosovo taking a front seat to Bosnia last year, which is a normal thing. The amount of money that they are willing to give us is decreasing. Everybody has scaled down or they have gone to Kosovo or their resources are redistributed.

Changes in tasks and priorities. By 2000, most NGOs and bilaterals focused on emergency or humanitarian post-conflict work recognized that it was time to leave Bosnia. The tasks and needs in Bosnia had changed to more traditional development and transition concerns. Far fewer organizations are involved in development than emergency relief. As a result, donors changed their priorities, which altered NGO activity. In some cases, NGOs changed their missions to adapt to the new demands. However, many commented that donors seemed to change based on political whims and unsound criteria to improve the situation on the ground.

There are certainly flashes of enthusiasm for areas. For example, in 97 or 98 Western Srpska was the sexy area and we did a spearhead return to that area with ARC. Within a few months there was money being flooded at us. Donors were coming up to us saying literally, we have $\$ 3$ million. Can you do the same for us as you did for EC? And then 6 months later there was a new sexy area. Well what about the other place? Well forget about that, they said. And that is exactly what happened.

\section{7b. Organizational Obstacles to Coop- erative, Coordinated and Collaborative Action}

Competition and overlap were also reported among the NGOs themselves. Many recognized that it was a problem, fueled by the nature of funding and the fact that there was no clear direction or leadership in the sector.

In other places I've worked there has been this subculture of NGOs not stepping on each other's turf. It's an informal thing. Usually we don't talk about those things when talking to our donors. But among ourselves we have that unspoken agreement. Here it is not so much that way. It's a bit more competitive.

Although some mentioned the lack of skills or vision necessary to coordinate action on the part of NGO directors or representatives, many more commented on the costs of coordinating activity. Implementers had more difficulty supporting such activities because they had to justify all their activities according to line items in their budgets. As one NGO director suggested, "It is hard to be devising a plan that will save millions. It is what is needed, something more sophisticated like that. But that is hard to sell to donors." Coordination was expected as an additional activity, and yet NGOs were too understaffed to simply add this function to their activities. Many commented on the time it takes to travel to and from meetings, given the poor roads, complaining that a meeting in nearby Mostar would take an entire day for someone in Sarajevo to attend. Others mentioned the impossibility of attending all the meetings they would like to while still keeping current with their own daily activities and management.

Coordination is often difficult because it's not just something you sort of fit in along with every thing else. You have to identify time within your agency to find the resources to do it. Someone has to find the time to go to meetings. 
Mission creep. Perhaps of greater importance in influencing the relationships between the NGOs - both local and international - and the IC were complaints about the rapid growth and decline of an enormous number of NGOs. Many noted that the majority of NGOs only arrived in response to the massive funding available. One contractor suggested that "so much money here so quickly, attracted a lot of folks." As a result of the massive growth in interest and the number of players on the ground, "a lot of international NGOs are running around doing the same thing and bit of competition has crept in." [Bilateral official] In response to this competition, the NGO community was criticized for mission creep, NGOs were reported to "do anything for a buck."

NGOs are like prostitutes. They will do anything for money. There was a lot of money for reconstruction, and even if they had never done it before, they were applying for money. And were did they learn about this? Nowhere! If you are in reconciliation or food distribution, maybe you should stay out of reconstruction.

Broadly accusing NGOs of mission creep seemed unfair, however, since they were responding to changing needs on the ground and the changing directions for international funding. In other words, donors largely dictated NGO activity. One worker commented, "NGOs don't have a lot of freedom to follow or define agendas unless they have an independent source of funding. Most NGOs are dependent on donor priorities."

Timing. NGOs also criticized the donor community. Complaints centered on the politics of donor funding and their need to target high-visibility, high-impact and highly quantifiable short-term projects, rather than more important long-term efforts, which were less glamorous and less tangible. One NGO director commented that "donors look at short-term prospects and 12 months later they move to a new place." Another suggested "donors only give money if it's about return and if there is a good chance it will be quantifiable ... since the need to show success by the donors drives the whole thing." And of course, many commented on the difference between donors. One official commented, "The American style is often very pushing and very effective. The EU style is different. It is the school you learned from, different management styles, different approaches to solving problems."

Experience. Many NGOs came with little or no experience in refugee return and reconstruction. However, over time, and supported by grants, they expanded their operations. As grants ended, they sought alternative income sources to support their overhead.

They build up a huge structure for a particular job. When that job is finished, however, they don't want to let people go, especially not the expats. You need to find a justification for them so you propose to do something else.

As a result, the nature of employment and need for different skill sets changed over time. "You don't need logistical people or emergency people now, you need more strategy and planning people." Another professional provided a counter-point:

It's getting worse and worse, the people who were here in the beginning were here to actually rebuild the country and to help the beneficiaries. Then on and on came more long-term people and strategic people who think about strategies and development. We come with 3-6 month contracts. They come with 1-2 year contracts and if they have no brilliant idea today, then they sit there until someone says they have to justify their existence.

But recognition of failed projects, difficulties and ineffective cooperative and coordinated action provided the greatest impetus to want better coordination. Donors and implementers simply began to realize that they were wasting money and not being as effective as they could be.

Organizational Culture. The expatriates who work in this sector are unique. With the exception of some bilateral and multilateral program managers, they are not aspiring diplomats. They work in the development world at low pay, under extreme conditions, on the front line of action, often in danger of great physical harm.

You get a lot of really bizarre people who do this; people who would be much better off in the French Foreign Legion. A lot of people drink too much. A lot of people have other drug problems. A lot of people are running away from all kinds of problems; problems at home, family problems, sexual problems. And they're all just a little bit crazy to begin with, and that definitely colors everybody's actions and perceptions of each other.

The volunteer nature and ground level intensity of action of volunteers tends to provide the biggest draw. One NGO volunteer who came during the war mentioned "I joined with 10 people, all who have never been here before. Some dropped out, some died." It is dangerous and exciting, and 
often these people move from crisis to crisis, traveling the world for new and different experiences. One worker explained, "People who are volunteers tend to stick in the field, on the sharp end, actually helping people." More importantly, local players are burdened with memories of the all too recent conflict - and limited resources to devote to development.

\section{7c. Managerial Obstacles to Coopera- tive, Coordinated and Collaborative Ac- tion}

Pay. The pay differences across the sectors - and between locals and internationals - created problems for individuals who were often bitter about counterparts that earned far more than they did for what they considered to be the same job. Others mentioned constraints for NGOs because they are unable to compete with the wealthier multilaterals and bilaterals, and therefore had a harder time hiring quality employees.

The nationals get much less. So it is hard to attract quality people with that. So you end up getting really young people with no experience, really old people, retired, or people who don't know what they are doing and you really wouldn't want to hire them normally.

You get what you pay for and if you are only going to pay people a certain amount then you are only gonna get people of a certain caliber and that's just begging for mistakes to be made. You will not find good business people here unless there are financial incentives at least equivalent to what they are doing currently.

The good people tend to get sucked up by World Bank, OHR, OSCE, UN and so forth. We can't compete. A donor will pay a driver a monthly wage of 1500 DM but when they give us money they say we can't pay our top local professor more than 400 DM.

Skills and Experience. Though often overcompensated for in terms of energy and commitment, skills and experience represent the biggest deficits in the NGOs. It is crucial to have some field experience working under such extreme conditions to be effective, especially experience in the Balkans. However, many others stressed that management skills are even more necessary; "People who are actually defining the skills that they are looking for are probably not qualified to actually make that definition anyway. It's the blind leading the blind."

Turnover presents a serious problem in this environment with strenuous conditions and low pay. There is a lot of burnout with NGOs who constantly seem to be looking for better employment. NGO workers typically have contracts that are dependent upon funding. They are offered few benefits, and no long-term security. As one low-paid NGO worker suggested, "If you are going to treat us like that, we're gonna leave." The turnover created problems with projects since the local authorities "learned that they can just wait few months and someone will leave and the new person will not have this institutional memory of what happened five years ago." As a result, many NGO workers spoke of the informal networking and recruitment that took place regularly.

You always network. A lot of people in this development world do. If you find a better paid job, then you jump, not all of us, but of course, the normal step is you come in a NGO after a while you try to find your way into OSCE or OHR or the World Bank.

You get headhunted a lot in this business, ARC just called me up. I turned them down, but if I had no sense of job security I would have been interested. That could be helped if donors took a longer perspective.

Frustration, Autonomy and Apathy. Perhaps the more dominant feeling among those in the refugee return and reconstruction sector was that they could not coordinate activity or improve cooperation since they had limited control over the activities of others. As such, many seemed apathetic about the situation, although they realized its enormous influence on their activities.

I can't tell CRS that they should do self-help. It's not my business. They are the ones that make their decisions and I can't tell them how to meet their objectives.

If you try to over coordinate it's not going to be that useful. You just sort of let it all happen; let the marketplace take its course. There will be bumps, but in the end it all works out. That is what has been happening here, the market in a sense.

As a result, a cooperative atmosphere simply did not exist. As one NGO director commented regarding a plan to coordinate more effectively, "Most people react against this with the fear that they are being coordinated." The NGOs 
were skeptical of coordination mechanisms that seemed to dictate what they should be doing.

These people won't come together. None of them tell the truth when it comes to particular political matters. They have these big high meetings where they bring everyone together four times a year, but they should be meeting twice a week.

Some donors were often criticized for acting autonomously, especially USAID. These negative comments, however, served to plant the initial seeds for cooperative action down the road. In addition, all stressed the overall necessity of USAID and often, of its approach. Recognizing these differences in style and form, many wished that there was one overall leader who could simply coordinate activity. However, they said so in an idealistic manner, usually following this by saying that that would be impossible due to the disparate nature of mandates and funding sources. A worker commented, "If it got better it would only get better if there was maybe just one person lending out money and one humanitarian aid person doing everything, but that goes against the whole system." It was odd, however, how many people commented on this, especially given the fact that the OHR's role was essentially overall coordination

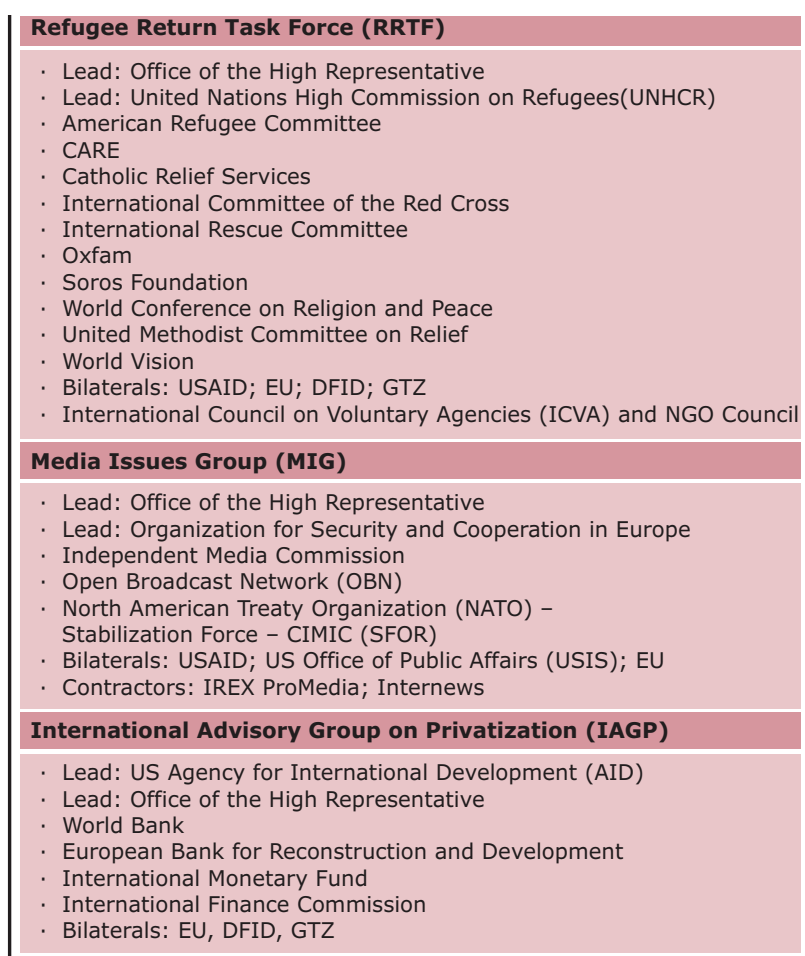

Table 1.

Representatives interviewed, by task force

\section{Discussion}

Organizational management provides a helpful practical lens as foreign assistance dollars are increasingly being implemented by task forces and networks, i.e. 'development by committee' (Martin, 2006). Sharing knowledge about best practices and cooperative experiences can hopefully help practitioners move beyond 'redeveloping wheels' in each new country they target by sharing best practices in programmatic activity (which is often done), as well as interorganizational, organizational, administrative or implementation level 'best practices' (less frequently accomplished). Scholars would provide a service by cataloging these experiences. Practitioners would also do well to share their experiences and determine when coordinated activity was in fact helpful and successful and when it simply served as a vehicle for donors and funders to feel as though work were more coordinated - without actual implications on the ground.

Donors often require coordinated activity, and yet are often blamed for establishing reporting requirements, funding schedules and activities that defy coordinated action. Such a dialog between donors and implementers must take place to insure effective action. It is my assertion that many obstacles to effective reform efforts lie not in the actual circumstances and dilemmas of development. Rather, they lie in the contextual, organizational and managerial dilemmas of 'development by committee' where external politics, international funding, organizational mandates, administrative procedures, organizational cultures and institutional logics tend to obscure potentially successful collaborative implementation mechanisms.

In order to solidify the lessons learned and apply them to the Bosnian experience in the future, as well as to potentially apply them to other countries going through similar situations, several key issues might be explored in more depth. Below I identify some areas for discussion, in which some solutions to the obstacles discussed above might be found.

a. Build Cross-sectoral Trust and Legitimacy. To achieve the goals mentioned above, NGOs must gain greater trust, respectability and perceived accountability to market their services to donors, both local and international, as well as peers, partners, constituents, and clients. Doing so requires investment in institutional strengthening efforts, public relations work, education, training and policy and political participation, but the sector is facing an increasing need 
to be seen as more responsible, accountable partners, and donors should allow funds for NGOs to do so. In addition, all players must recognize the strengths and limitations of organizations in each of the sectors, both locally and internationally, on a more institutional basis.

b. Legitimize Mission Creep. Development organizations have been accused, perhaps unfairly, of extraordinary mission creep; a devolution of activity away from their original mission and, likely, their core competencies. However, $\mathrm{BiH}$ went through enormous changes in the last decade so we might expect the organizations serving that population to evolve as well. Stability, niche identification, and coordinated - not necessarily collaborative - action can accommodate mission creep. As long as organizations are part of a coordinated system, funders concerns over overlap and waste will be minimized. The actions of individual players could vary within such a system. The negative stigma associated with mission creep should be tempered. Private sector firms who do this are thought to be adaptive and innovative. Perhaps the same courtesy could be extended to NGOs.

c. Strengthen Institutional Strengthening. Development organizations must take time to recharge their organizations and 'professionalize' as best as possible. This requires higher salaries, lower turnover, educational opportunities, and a targeted effort to train and develop lower level volunteers and staff. Skills necessary include finance, information technology, marketing, management, strategy, operations, and human resource management. Donors might encourage NGOs to invest in themselves and the processes through which they deliver results rather than being so preoccupied with only the accomplishment of tasks - an understandably difficult trade-off.

d. Self-regulate. Development organizations across the spectrum have been accused of waste and inefficiencies. The international donors are as much to blame for this as the NGOs and development institutions themselves. This should be addressed locally, taking important issues to locally based (whether international or local players) networks and allowing them to develop a voice. That collective voice, however, has many subsets and the re-organization of the entire industry might evolve simultaneously. Regardless, players in development work need to be sure that in identifying task failures and less effective organizations, they do not throw out the proverbial baby with the bathwater. The development of common standards, assessment tools and best practice guides would help. e. Get to "Post-Post Conflict". Bosnia had been burdened with the post-conflict tag for thirteen years. While that allows access to some specific sources of funding and support, practitioners need to reposition their work when they believe they are 'POST-post-conflict.' Doing so requires a coordinated, cross-sectoral effort to communicate when the country has indeed moved to a new phase in its development. It seems odd, for example, that during my travels to Bosnia, professionals were receiving danger pay, especially compared to truly dangerous settings like Iraq. This creates a negative impression that may be counterproductive. It also serves to increase pay and salary, which may not be completely justified in more highly desirable expatriate placements.

f. Operationalize Civil Society Building. Civil society is an enormous and overused catchphrase. The term serves as both a major funding avenue in and of itself, as well as a required component or condition of many varied sources of support. Local development institutions and particularly NGOs and local bilateral missions must embrace the concept and inculcate it into their missions. It is the core of their existence and thus should be more measurable in terms of memberships, donations, political influence, etc. as a potential indicator of local ownership - an important buzzword in development circles. By recognizing that civil society development is critical to all the reform efforts mentioned above, and indicating how it is being addressed in each, this misunderstood and vaguely described concept in development might become more commonly understood.

g. Encourage Ownership. A key concept in development circles is that of creating a demand for locals to 'own' their reform efforts. As such, some see projects such as the Bulldozer Committee as a classic example of local ownership since local business people suggested the reforms. Others counter that the International Community and the OHR were the real backbones of this initiative and it is not local at all, rather the locals are being used by the Internationals to make it seem as though this were a bottom-up charge. Regardless, efforts must be made to pass the torch on to locals from the very beginning. While this long process involves a great deal of mentoring at a time of great stress and urgency early in any intervention, it is time perhaps ultimately well spent.

h. Avoid Moral hazard. The theory goes that the more the international community does, the less locals need to do. As such, in an effort to turn things over to the locals, the IC should be more hands-off and not try to push through 
reforms, as the reform itself is not the key outcome. In situations like Bosnia, this remains an empirical question, which must rely on the interpretations of local officials as much as internationals. As such, politicians and observers need to be more patient with some reform efforts and need to carefully choose which projects are so 'critical' that they necessitate bypassing local decision makers. The test should be a strict one.

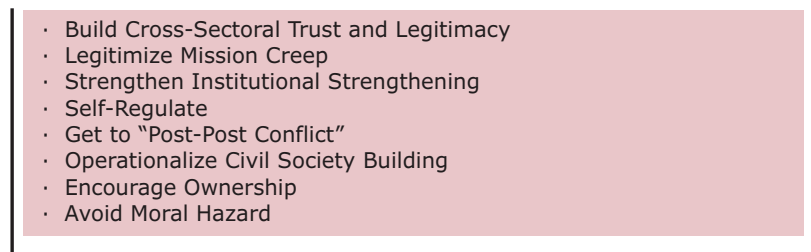

Table 3.

Strategic Directions to Overcome Obstacles

\section{Conclusions}

This paper serves to identify lessons learned from the International Community's experiences in BiH. Many of these insights address the need for even more cooperative, coordinated and collaborative activity - for purely pragmatic reasons, not simply political correctness. The tasks at hand in such situations are so overwhelming that vehicles need to emerge that can handle large scale, complex problems through strategic, systematic approaches that cannot be unilateral - if only for the sheer size and scope, let alone relative appreciation for core competencies and political leverage that certain players might have.

The task forces above were created for this reason and all participants would certainly recognize improvements could be made. These professionals would also stress, however, that improvements require primarily increased time to develop trust, understanding, mutual respect and legitimacy. Such 'time' often doesn't exist in complex humanitarian emergencies and potentially explosive nation building activities where immediate action is required. Cooperation cannot be mandated, it develops between people. Coordination and collaboration, can, of course, be mandated, but without cooperation, more embedded relational forms lack the foundation necessary for success.

The international community served as the major focus of this piece. It is hoped that readers recognize this only as the perspective through which this research took place, in a descriptive, positive fashion. It is not meant to imply that the international community is the sole or even primary actor. The principle of ownership weighed heavily in most in- terviews. Local ownership, participation and commitment remain at the forefront of development success. As such, the question of dependency surfaced often.

Through inclusion, the benefits of international action should offset the long-term negative effects of dependen$c y$, though this remains to be tested. Inclusion materializes through interorganizational relationships between the international community and host country players that foster increased ties and embeddedness. Table 2 summarizes the results of my exploration into some of these 'inclusive' vehicles.

Respondents suggested overwhelmingly that the key motivators for collective action included the ability to provide a forum to discuss lessons learned and best practices. In addition, such cooperative activity fosters the identification of niches and areas of overlap. Solutions typically require coordinated activity. Finally, a principal motivator to work together included the ability to speak in one voice and develop common advocacy positions. This implies collaborative activity on the part of participants.

A hierarchy of collective activity emerged in through this work. Effective collective action requires cooperation, coordinated action, and collaborative activity - in that order. These stages of collective action require increasing embeddedness and ties between stakeholders, as they move from initial cooperative activity in terms of sharing and receptiveness to outside input; to coordinated activity that requires discussion of current and future organizational strategies and the desire to find synergies and coordinate responses; to collaboration, which requires internal change to organizational activity, as a result of strong partnerships and trust.

The obstacles to such cooperative, coordinated and collaborative collective action identified in this research are well documented in the development literature. Local obstruction to reforms, dramatic funding swings and overall priority changes serve as contextual obstacles that lie outside the control of most organizational players. Organizational obstacles, such as competition, mission creep, time perspectives, experience and culture can be internalized by organizations committed to success. Managerial obstacles include pay discrepancies between host country nationals and expatriates, employee skills and experience, turnover and apathy. While both managerial and organizational obstacles can be solved, doing so requires resources. And these resources potentially take away from those devoted 
to task completion- a difficult tradeoff to make.

Table 3 suggests that many of the potential solutions to these obstacles do not, however, require extensive resources. Instead, they require cultural shifts among participants. Trust and legitimacy, encouraging ownership, and avoiding moral hazards all take time, but do not necessarily translate into increased direct costs. In addition, legitimizing mission creep requires no financial support. Mission creep is seen as one of the "deadly sins" in the nonprofit world. However, in circumstances where change is so dramatic in such short time horizons, mission creep might not be as negative as many suggest.

Institutional strengthening and operationalizing civil society does, indeed, cost money. Resources should be spent in these two areas, demonstrating a long-term commitment to change and development in terms of positioning and assessment that might potentially mitigate the concerns of dependency. If local institutions are prepared to handle tasks, and these tasks are well identified, operationalized and measurable, perhaps more local ownership of reforms would result.

This article might prove useful to several audiences. First, for those who explore and research international development assistance, it reiterates the influence of the local environment on coordinated activity among and between the many players on the ground. As recent experiences in Kosovo, Afghanistan, East Timor and Iraq demonstrate, the international community increasingly supports interventions that attempt to speed up the development process by tackling multiple goals simultaneously. While this may be an efficient use of time in a world pre-occupied with the speed of reform, it creates complexities on the ground that may actually decrease efficiency and effectiveness.

For those actually engaged in coordination efforts, task forces, or even lead organizations, the research reported above might assist developing strategies for overcoming obvious obstacles to success. Recently, the UN created its peacebuilding agency as a potential lead organization designed to oversee such complex humanitarian crises. My research demonstrates that unless this organization can overcome the obstacles mentioned above, it is doomed to further complicate matters by simply becoming yet another agency with coordination needs and fears. The OHR in $\mathrm{BiH}$ was created in part to serve as such a coordinating body. Coordination without hierarchy seems to be the general consensus for success. A UN agency, however, seems likely to be a bureaucratic command and control oriented organization that will also likely take a lot of blame for situations beyond its control. It is one of several approaches to the coordination issue. However, if they are to succeed in such a role, they must gain the legitimacy and power necessary - which means budgetary power. Without it, success seems unlikely.

For practitioners, this work might help identify obstacles to projects that were perhaps outside of their responsibilities. More attention should be paid by donors and contractors to specifically identifying solutions, and crafting contracts to reflect the actual process and means to achieving success, rather than being largely based on end results. For example, a recent call for proposals in Iraq promises some potentially interesting material for study. The call was not for project- or sector-specific activity. Rather it asked applicants to propose addressing all of the needs of one area, thus being geographically based. Perhaps coordination efforts under the regional control of one lead agency or contractor might prove more successful than those between lead agencies on different intertwined efforts across geographic regions.

Finally, for those who study interorganizational relationships, this case raises the need for careful attention to complex settings like Bosnia where external control and variables subvert the best intentions of potential partners. This raises interesting theoretical insights into the structure, strategy and process of IORs and the true determinants of their success, with careful consideration and respect to the environment or context within which they operate. Much of the mainstream IOR literature is based upon private sector studies in developed nations, essentially controlling for context. IOR research in areas where the environment is clearly'uncontrollable' might prove useful. $[$. 


\section{References}

Belloni, Roberto (2001). Civil society and peacebuilding inBosnia and Herzegovina. Journal of Peace Research 38(2): 163-180.

Borton, John (1995) An account of co-ordination mechanisms for humanitarian assistance during the international response to the 1994 crisis in Rwanda. Disasters, Overseas Development Institute 20(4): 305-323.

Boyce, J.K. (1995). External Assistance and the Peace Process in El Salvador. World Development 23(12): 2101-2116.

Boyce, J.K. (1995). Adjustment toward peace: an introduction. World Development 23(12): 2067-2077.

Brinkerhoff, Derick W. (1999). Exploring state-civil society collaboration: Policy parternships in developing countries. Nonprofit and Voluntary Sector Quarterly 28(4), Supplement: 59-86.

Brinkerhoff, D.W. (1996). Coordination issues in policy implementation networks: An illustration from Madagascar's environmental action plan. World Development 24(9):1497-1510.

Brinkerhoff, Derick W. and Brinkerhoff, Jennifer M. (2004).Partnerships between international donors and non-governmental development organizations: Opportunities and constraints. International Review of Administrative Sciences 70(2):253-270.

Brinkerhoff, Derick W. and Brinkerhoff, Jennifer M. (2002). Governance reforms and failed states: Challenges and implications. International Review of Administrative Sciences 68: 511-531.

Brinkerhoff, J.M. (2002). Government-Nonprofit partnership: A defining framework. Public Administration and Development 22 19-30.

Brinkerhoff, J.M. and Brinkerhoff, D.W. (2002). Government-Nonprofit relations in comparative perspective: Evolution, themes and new directions. Public Administration and Development 22 3-18.

Clark, John (1995). The state, popular participation and the voluntary sector. World Development 23(4): 593-601.

Del Castillo, Graciana (2001). Post-conflict reconstruction and the challenge to international organizations: the case of El Salvador. World Development 29(12): 1967-1985.
Donais, Timothy (2002). The politics of privatization in post-Dayton Bosnia. Southeastern European Politics 3(1): 3-19.

Edwards, Michael (1999). International development NGOs: Agents of foreign aid or vehicles for

international cooperation? Nonprofit and Voluntary Sector Quarterly 28(4), Supplement: 25-37.

Ellerman, D.P. (1999) Global Institutions: Transforming international development agencies into learning organizations. Academy of Management Executive 13(1): 25-35.

Evans, P. (1996). Introduction: Development strategies across the public-private divide. World Development 24(6): 1033-1037.

Francis, David J. (2000). Torturous path to peace: The Lome Accord and postwar peacebuilding in Sierra Leone. Security Dialogue 31(3): 357-373.

Goldsmith, A.A. (1996). Strategic thinking in international development: Using management tools to see the big picture. World Development 24(9): 1431-1439.

Griffin, Michele (2000). Where angels fear to tread: Trends in international intervention. Security Dialogue 31(4): 421-435.

Hamre, John and Sullivan, Gordon (2002). Toward Postconflict Reconstruction. The Washington Quarterly 25(4): 85-96.

Hardy, Cynthia and Phillips, Nelson (1998). Strategies of engagement: Lessons from the critical examination of collaboration and conflict in an interorganizational domain. Organization Science 9(2): 217-230.

Hasic, Tigran (2006). Management of Complexities in Post-War Reconstruction (BiH and the International Community). South East European Journal of Economics and Business, February 2006: 6-17.

Hasic, Tigran and Bhandari, Saurabh (2001). New Outlooks on Reshaping and Revitalizing Post-Conflict Regions: Strategies, Principles and Models for Reconstruction. Paper presented at the 41st Congress of the European Regional Science Association (ERSA), Zagreb, August.

Hill, Hal (2001). Tiny, poor and war-torn: Development policy challenges for East Timor. World Development 29(7): 1137-1156.

Huddleston, M.W. (1999). Innocents abroad: Reflections from a public administration consultant in Bosnia. Public Administration Review 59(2): 147-157.

Judd, Lord (1992). Disaster relief or relief disaster: A challenge to the international community. Disasters 16(1): 1-8. 
Kiggundu, M.N. (1996). Integrating strategic management tasks into implementing agencies: From firefighting to prevention. World Development 24(9): 1417-1430.

Knaus, Gerald and Martin, Felix (2003). Lessons from Bosnia and Herzegovnia: Travails of the European Raj. Journal of Democracy 14(3): 60-74.

Lammers, C.J. (1988). The interorganizational control of an occupied country. Administrative Science Quarterly (33): 438-457.

Lawrence, T.B. and Hardy, C. (1999). Building Bridges for Refugees: Toward a typology of Bridging organizations.

The Journal of Applied Behavioral Science 35(1): 48-70.

Maley, William (2002). Twelve theses on the impact of humanitarian intervention. Security Dialogue 33(3): 265-278.

Martin, E. (2006). The Co-Evolution of Development Needs and IOR Form: Development by Committee. International Public Management Journal. 10(1): 59-77.

Martin, E., Faerman, S. and McCaffrey,D. (2006).Cooperation After War: International Development in Bosnia, 1995 to 1999. Managing Global Transitions 4(3): 215-230.

Martin, E. (2004). Privatization in Bosnia and the Craft of IOR Process Analysis. Organization Studies 25(7): 1115-1157.

Martin, E. and Miller, J. (2003). Developing Bosnia and Herzegovina: Understanding Large-Scale Interorganizational Systems. Voluntas 14(2): 145-166.

McCracken, G. (1988). The long interview. Sage Publications. CA.Ofstad, Arve (2002). Countries in violent conflict and aid strategies: The case of Sri Lanka. World Development 30(2): 165-180.

Pritchett, Lant and Woolcock, Michael (2004). Solutions when the solution is the problem: Arraying the disarray in development. World Development 32(2): 191-212.

Pugh, Michael (2000). Civil-military relations in the Kosovo crisis: An emerging hegemony? Security Dialogue 31(2): 229-242.

Ricigliano, Robert (2003). Networks of effective action: Implementing an integrated approach to peacebuilding. Security Dialogue 34(4): 445-462.

Roberts, Nancy C. and Bradley, Raymond T. (2005). Organizing for Peace Operations. Public Management Review 7(1):111-133.

Rondinelli, D. (1982). The dilemma of development administration: Complexity and uncertainty in control-oriented bureaucracies.

World Politics 35(1): 43-72.

Rondinelli, D. and Black, S.S. (2000). Multinational strategic alliances and acquisitions in Central and Eastern Europe: Partnerships in privatization. Academy of Management Executive 14(4): 85-98.

Rondinelli, D.A. and London, T. (2003). How corporations and environmental groups cooperate: Assessing cross-sector alliances and collaborations. Academy of Management Executive. 17(1): 61-76.

Strauss, A. and Corbin, J. (1990). Basics of Qualitative Research. Sage Publications, CA.Talentino, Andrea K. (2002). Intervention as nation-building: Illusion or possibility? Security Dialogue 33(1): 27-43.

Vargas, C.M. (2002). Women in sustainable development: Empowerment though partnerships for healthy living. World Development 30(9): 1539-1560.

Walker, Peter (1993). Foreign military resources for disaster relief: An NGO perspective. Disasters 16(2): 152-159.

Weis, Thomas G. (2001). Researching humanitarian intervention: Some lessons. Journal of Peace Research 38(4): 419-428.

Westley, F. and Vrandenburg, H. (1997). Interorganizational collaboraton and the preservation of global diversity. Organization Science 8(4): 381-403. 